\title{
Dietary Intake and Socio-economic Predictors of Inadequate Energy and Nutrient Intake Among Women of Child Bearing Age in Karamoja Sub-region of Uganda
}

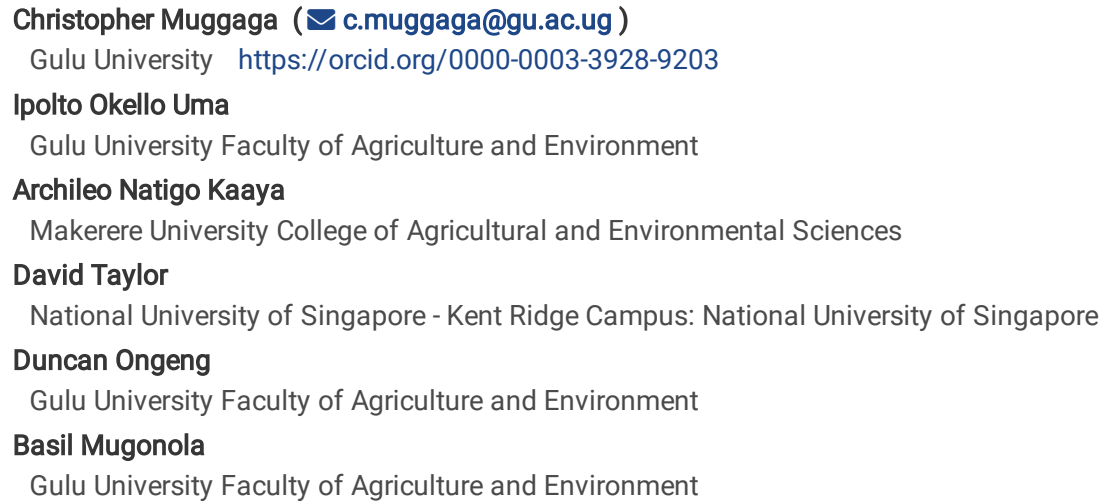




\section{Abstract}

Background: Karamoja sub-region is the most food insecure part of Eastern Africa. The poor status of food security in the sub-region is reflected in the high rate of undernutrition among women of child bearing age (WCBA) and children under five years (CUFY). The sub-region is unique in Uganda in terms of cultural diversity, agro-ecology and rainfall pattern, and agricultural practices. However, the influence of these unique characteristics on dietary intake of WCBA in the sub-region is less understood. Therefore, this study examined dietary intake and socio-economic predictors of inadequate energy and nutrient intake among WCBA in Karamoja sub-region.

Methods: A longitudinal study design was used involving 755 WCBA in the harvesting season where 635 were followed-up in the planting season. Data were collected using 24-hour recall, dietary diversity, and socio-economic and demographic questionnaires.

Results: Intake of energy and nutrients were generally significantly higher $(p<0.05)$ during the planting season than in the harvesting season. Irrespective of the district, physiological status and season, household consumption of plant-based foods was far higher than intake of animal-based foods dominated by starchy stables (76-100\%), dark green leafy vegetables (70-100\%) and legumes, nuts and seeds (22-97\%) depending on the district. Majority of the respondents had two meals (breakfast: $65-100 \%$; supper: $90-100 \%$ ) with up to $45 \%$ of WCBA who consumed alcohol across meal times. Overall on average, $57.7,66.6,78.5,60.3,67.7$ and $93.7 \%$ of WCBA did not meet the Recommended Daily Allowance (RDA) for energy, protein, calcium, iron, zinc and folic acid, respectively. Binary logistic regression revealed that inadequate intake of energy and nutrients significantly increased $(p<0.05)$ with the status of being Lactating/breastfeeding, and was influenced by age of WCBA, number of women married, education level and occupation of the household head depending on season.

Conclusions: This study demonstrated that dietary intake of WCBA in Karamoja sub-region was inadequate. Age of WCBA, number of women married, education level and occupation of the household head and spouse, and being a lactating/breastfeeding mother were the key socio-economic and demographic factors that influenced inadequate intake of energy and nutrients among WCBA.

\section{Background}

Maternal undernutrition is endemic in most countries in sub-Saharan Africa (SSA), with more than $20 \%$ of women in the sub-continent having a body-mass index of less than $18.5 \mathrm{~kg} / \mathrm{m}^{2}$ [1]. The prevalence of maternal malnutrition is still high in SSA where maternal underweight exceeds $20 \%$ in some countries with exception of few countries such as Benin, Cameroon, Ghana, Lesotho, Rwanda, Swaziland, and Togo [2]. Maternal undernutrition is responsible for several global challenges in which poor child survival, incidence of acute and chronic diseases, unhealthy development, and low economic productivity [3], low birth weight, stunting and poor cognitive development [4] are implicated. Maternal malnutrition is of particular importance because of the fact that nutrition in the first 1000 days of human life is critical for subsequent development $[5,6,7,8]$. During this period, there is rapid growth and development, fastest rate of neurodevelopment of cognitive functions, maturation of all organ systems, and establishment of metabolic patterns [8, 9, 10, 11]. As such, maternal nutrition before and after conception is a major focus for government and development agencies, with national commitments in low-income and middle-income countries (LMICs), increased donor funding and civil society and private sector engagement [12]. Examples of such engagements include Scaling Up Nutrition (SUN) as a framework for action 2011 [13], Multi-Sectoral Nutrition Strategy 2014-2025 [7], Global Governance for Nutrition and the role of UNSCN [14], and Civil society participation in global public private partnerships for health [15].

Malnutrition is also a major development concern in Uganda, affecting all regions of the country. For instance, the previous three Demographic and Health Surveys (DHS) $(2006,2011,2016)$ indicate that undernutrition is on decline but the progress is very slow. The report indicates that among women the prevalence of anemia reduced from $49 \%$ in 2006 to to $32 \% \%$ in $2016[16,17]$. It is generally recognized that women and children in Uganda continue to experience deficiencies of vitamin A and zinc [18] there is lack of national data on the extent of deficiency.

Karamoja sub-region in Uganda has disproportionately high prevalence of malnutrition driven by high levels of food insecurity. Regarding maternal nutrition, undernutrition among WCBA is disproportionately high while health indicators are poor. For instance, $32 \%$ of WCBA in the sub-region were found to be anemic [17]. On the other hand, $30 \%$ and $12 \%$ of the population experience stress and crisis level food insecurity [19]. Food insecurity in the sub-region exists amidst very complex situations comprising marked differences in terms of ethnic groups [20,21, 22], agroecological zones [21, 22] and livelihood strategies [23]. Added to this, is seasonal availability of food [24,25], which further exacerbates food insecurity and access to a well balanced diet. The existing disparities in food and nutrition security situation in Karamoja sub-region [26] could partly be attributed to these complex situations and influence nutrient intake among WCBA. However, empirical data to support dietary intake are largely lacking. Hitherto, it is widely acknowledged that nutrition of mothers has a great impact on their health, including the health of children [11, 27-31], Accordingly, the current study focused on understanding the dietary intake and socio-economic predictors of inadequate energy and nutrient intake by WCBA. This study makes contribution to the efforts in improving maternal nutrition in communities that are resource constrained and have poor state of human development indicators such as Karamoja sub-region. Understanding dietary intake of WCBA such circumstances would constitute the basis for designing strategies to reduce the adverse consequences of food and nutrition insecurity on maternal nutrition.

\section{Methods}

The main aim of the study was to investigate dietary intake and socio-economic predictors of inadequate energy and nutrient intake among WCBA in Karamoja sub-region. A longitudinal design was used. Accordingly, 755 WCBA participated during the first visit (October to December 2014) of the study corresponding to the harvesting season. Of these women, 635 were followed (April to June 2015) in a period coinciding with the planting season [32]. The sample size was established using a standard formula [33]. A multi-stage sampling technique was used to select study participants based on livelihood zones [22, 34, 35], geographical locations [23] and ethnic group inclusiveness [20-22]. Hence, Abim, Amudat, Kaabong, and Moroto were selected in the first stage. In the second stage, simple random sampling was used to obtain two sub-counties per district. The selected sub-counties were Alerek, Morulem, Kathile, Sidok,

Page 2/16 
Nadunget, Rupa, Loro and Amudat. In the third stage, two parishes were randomly selected from the sub-counties. In the fourth stage, two villages were randomly selected from each of the selected parishes. A total of 32 villages were selected.

Finally, assisted by members of village health teams and local council officials, participants in each physiological category (pregnant women, lactating mothers and non pregnant women) in the selected villages were enrolled

Data were collected with the help of trained research assistants who were resident in the selected districts and fluent in their respective local languages. These research assistants were able to interpreting the questions from English to the local languages during face-to face interviews. Dietary assessment was carried out using the Household Dietary Diversity Score-HDDS [36] and 24-Hour Dietary Recall [37] to determine dietary quality and nutrient intake, respectively. Information on HDDS was obtained through a recall of all foods/drinks consumed in the household in the previous 24 hours. Prior to conducting 24 -Hour Dietary Recall, the common staples: sorghum, maize, millet were also prepared by one of the households in different forms such as bread, boiled grains that are commonly consumed in the area. Similarly, sauces from green vegetables, beans were prepared. During the 24-Hour Recall interviews, the portion sizes of the solid foods consumed in the previous 24 -hour period were weighed (in grams). For all foods, which were liquid or semisolid such as porridge, tea, milk, water was poured in a calibrated cup to estimate the volume consumed. These were followed by calculations of energy and nutrient composition (carbohydrates, proteins, calcium, iron, zinc, folic acid) from the portion sizes of individual foods and ingredients consumed by each participant using the Harvest Plus food composition table for central and eastern Uganda [38]. To assess the socio-economic and demographic status of the women and their household, information on age, marital status, family type, occupation, and education level were gathered.

Data on socio-economic and demographic characteristics, and dietary diversity were analyzed using descriptive statistics and expressed as the proportions. The mean energy and nutrient intake between seasons for each district was compared using paired sample t-test at $5 \%$ significance level $(P<0.05)$. Data from the 24-Hour Dietary Recall were first used to generate meal patterns of respondents and presented as line graphs. To determine the level of inadequacy of energy and nutrient intake, Recommended Daily Allowances (RDAs) for energy [39] and nutrients [40] for each physiological status were used where "1" was assigned to respondents with adequate intake and " 0 " to respondents with inadequate intake. This data were summarized as proportion of WCBA with inadequate intake of energy and nutrients. Finally, a linear regression was used to determine socio-economic and demographic predictors of inadequate energy and nutrient intakes among WCBA. The regression model used is presented in Equation 1:

$$
Y_{i}=\beta_{0}+\beta_{1} X_{1}+\beta_{2} X_{2}+\ldots \ldots . \beta_{n} X_{n}+\mu
$$

Where:

$\mathrm{Yi}$ is the dependent variable describing the status of intake of energy, proteins, calcium, iron, zinc, folate and vitamin $A$. $\beta_{0}$ is the regression constant; $\beta$ is the regression coefficient; and $\mu$ is the error term. $X$ denotes independent variables that were used to run the binary logistic regression. Before actual regression analysis, correlation analysis (Pearson) was performed to eliminate highly correlated dependent variables with coefficient greater than 0.70 [41]. Following correlation analysis, the following variables were used in the regression test: physiological status, age, marital status, family type, number of women married, occupation of the woman, occupation of the household head, education status of woman and education status of the household head. These variables, their description/measurement and the priori expected sign are presented in Table 1.

Table 1

Variables, description/measurement and the priori expected sign

\begin{tabular}{|c|c|c|c|}
\hline $\begin{array}{l}\text { Dependent } \\
\text { variable }\end{array}$ & Description & Variable coding/Definition & $\begin{array}{l}\text { Expected priori } \\
\text { sign }\end{array}$ \\
\hline$x_{1}$ & Pregnant & $\begin{array}{l}\text { Pregnant women }=1 \text {, none pregnant women and lactating } \\
\text { mothers }=0\end{array}$ & + or - \\
\hline$x_{2}$ & Lactating & $\begin{array}{l}\text { Lactating women }=1 \text {, none pregnant women and Pregnant } \\
\text { women }=0\end{array}$ & + or - \\
\hline$x_{3}$ & Age in completed years & & + or - \\
\hline $\mathrm{x}_{4}$ & Polygamous & Polygamous $=1$, Monogamous $=0$ & + or - \\
\hline$x_{5}$ & Marital status & married $=1$, not married, widowed, single or divorced $=0$ & + or - \\
\hline$x_{6}$ & Occupation of the household head & formally employed $=1$, not formally employed $=0$ & + or - \\
\hline$x_{7}$ & Occupation of woman in the household & formally employed $=1$, not formally employed $=0$ & + or - \\
\hline$x_{8}$ & Education status of household head & formally educated $=1$, not educated $=0$ & + or - \\
\hline$X_{9}$ & $\begin{array}{l}\text { Education status of the woman in the } \\
\text { household }\end{array}$ & formally educated $=1$, not educated $=0$ & + or - \\
\hline$x_{10}$ & Number of women married & one woman $=1$, more than one women $=0$ & + or - \\
\hline
\end{tabular}

All statistical analyses were performed using GenStat Version 12 and IBM Statistical package for Social Scientists (SPSS) version 20 and STATA. 


\section{Results}

Socio-economic and demographic characteristics of the study participants are summarized in Table 2. Irrespective of season, majority of the participants were in the age category of $20-29$ years (41-51\%), followed by those in the age bracket of 30-39 years (25-34\%). Abim and Amudat districts had the highest proportion of teenage mothers. Most of the WCBA surveyed were married accounting for $85.5-95 \%$. More than half of WCBA were in monogamous relationships, except in Abim district where the proportion was much lower (12.5\%) with about $60 \%$ in polygamous relationships (approximately double that in other districts). In all districts, subsistence farming was the major occupation employing $62-95 \%$ of WCBA. These women also commonly participated in tree cutting (for firewood and charcoal production) and brewing in Moroto and Kaabong. Generally, education attainment by WCBA was very low in Amudat and Moroto. More than $90 \%$ of WCBA in Moroto and Amudat, and $62.8 \%$ in Kaabong had not received any formal education. The proportion of those who had received formal education was highest in Abim, where more than $70 \%$ of participants had spent some time at school.

Table 2

Socio-economic and demographic characteristics of the respondents (\%) segregated by district.

\begin{tabular}{|c|c|c|c|c|}
\hline \multirow[t]{2}{*}{ Category } & \multicolumn{3}{|c|}{ District } & \multirow[b]{2}{*}{ Amudat } \\
\hline & Abim & Kaabong & Moroto & \\
\hline \multicolumn{5}{|l|}{ Physiological status } \\
\hline Pregnant & $33.9(12.2)$ & $33.2(8.5)$ & $33.5(11.5)$ & $33.5(14.2)$ \\
\hline Lactating & $33.9(57.9)$ & $33.7(55.8)$ & $36.8(63.0)$ & $37.8(63.8)$ \\
\hline Non Pregnant & $32.3(29.9)$ & $33.2(32.7)$ & $29.7(8.5)$ & $28.6(22.0)$ \\
\hline $\mathbf{N}$ & $192(164)$ & $190(165)$ & $185(165)$ & $185(141)$ \\
\hline \multicolumn{5}{|l|}{ Age } \\
\hline 15-17 Years & $1.6(0.6)$ & $3.2(3.6)$ & $6.0(5.7)$ & $5.6(3.6)$ \\
\hline 18-19 Years & $12.0(8.6)$ & $5.9(6.7)$ & $4.9(7.6)$ & $6.7(6.5)$ \\
\hline 20-29 Years & $49.5(51.5)$ & $51.3(40.6)$ & $51.6(48.4)$ & $49.4(50.7)$ \\
\hline 30-39 Years & $33.9(30.1)$ & 33.7 (33.9) & $24.7(29.9)$ & 30.9 (31.2) \\
\hline 40-49 Years & $3.1(9.2)$ & $5.9(15.2)$ & $12.6(8.3)$ & $7.3(8.0)$ \\
\hline $\mathbf{N}$ & $192(163)$ & $187(165)$ & $182(157)$ & $178(138)$ \\
\hline \multicolumn{5}{|l|}{ Marital status } \\
\hline Married & $92.7(93.9)$ & $86.8(84.8)$ & $85.4(88.5)$ & $95.0(97.2)$ \\
\hline Single & $1.6(1.2)$ & $12.6(12.1)$ & $11.4(10.3)$ & $5.0(1.4)$ \\
\hline Widowed & $4.1(3.1)$ & $0.5(3.0)$ & $3.2(1.2)$ & $(1.4)$ \\
\hline Divorced & $1.6(1.8)$ & & & \\
\hline $\mathbf{N}$ & 192(163) & $190(165)$ & $185(165)$ & $180(141)$ \\
\hline \multicolumn{5}{|l|}{ Family type } \\
\hline Polygamous Family & $60.6(60.1)$ & $35.3(34.8)$ & $29.7(33.5)$ & $33.3(34.8)$ \\
\hline Monogamous Family & $12.8(24.5)$ & $56.3(51.8)$ & $55.2(60.1)$ & $59.2(58.9)$ \\
\hline Monogamous Extended Family & $17.0(7.8)$ & $1.22 .4)$ & $4.8(0.6)$ & 1.1 \\
\hline Polygamous Extended Family & $9.5(8.0)$ & $7.2(11.0)$ & $10.3(5.7)$ & $6.3(6.4)$ \\
\hline $\mathbf{N}$ & $188(163)$ & $167(164)$ & $165(158)$ & $174(141)$ \\
\hline
\end{tabular}


Table 2

Continue:

\begin{tabular}{|c|c|c|c|c|}
\hline \multirow[t]{2}{*}{ Category } & \multicolumn{3}{|c|}{ District } & \multirow[b]{2}{*}{ Amudat } \\
\hline & Abim & Kaabong & Moroto & \\
\hline \multicolumn{5}{|c|}{ Occupation of Household head } \\
\hline Farmer/Gardener & $61.8(63.0)$ & $67.0(90.6)$ & $50.0(46.0)$ & $48.3(71.2)$ \\
\hline Trader/Seller & $3.9(5.2)$ & 0.6 & $1.8(3.1)$ & $15.3(10.8)$ \\
\hline Casual labourer & 0.6 & $1.1(1.3)$ & $4.1(1.8)$ & $(0.7)$ \\
\hline Civil Servant & $13.5(20.1)$ & $10.6(4.4)$ & $4.1(3.1)$ & $2.8(1.4)$ \\
\hline Pastoralist & & 0.6 & $0.6(1.2)$ & $26.7(12.9)$ \\
\hline Agropastoralist & & & $1.8(1.2)$ & \\
\hline Gold mining & & $1.1(0.6)$ & $2.4(5.5)$ & 0.6 \\
\hline Fire wood sale & & 1.1 & $1.8(0.6)$ & \\
\hline Brewing & & $(3.1)$ & $(4.3)$ & \\
\hline Charcoal Burning & & 15.1 & $31.8(30.7)$ & $1.1(0.7)$ \\
\hline Others & $20.2(11.7)$ & 2.8 & $1.8(2.5)$ & $5.1(2.2)$ \\
\hline $\mathbf{N}$ & $178(154)$ & 179 (159) & $170(163)$ & $176(139)$ \\
\hline \multicolumn{5}{|c|}{ Occupation of women } \\
\hline Farmer/Gardener & $94.8(98.2)$ & $70.4(99.4)$ & $53.8(42.4)$ & 91.4 (97.9) \\
\hline Trader/Seller & $3.1(1.2)$ & 0.6 & 0.5 & $2.9(1.4)$ \\
\hline Casual labourer & & & $2.7(4.8)$ & $1.1(0.7$ \\
\hline Civil Servant & 0.6 & & & \\
\hline Gold mining & & & $(4.8)$ & \\
\hline Fire wood sale & & 3.9 & $14.3(10.3)$ & 1.7 \\
\hline Brewing & 1.6 & 10.6 & $7.1(8.5)$ & \\
\hline Charcoal Burning & $(0.6)$ & $13.4(0.6)$ & $21.4(29.1)$ & 1.1 \\
\hline Others & & 1.1 & & 1.7 \\
\hline $\mathbf{N}$ & $192(163)$ & 179 (164) & $182(165)$ & $175(141)$ \\
\hline
\end{tabular}

Table 2

Continue:

\begin{tabular}{|lllll|}
\hline Category & \multicolumn{4}{c|}{ District } \\
\cline { 2 - 5 } & Abim & Kaabong & Moroto & Amudat \\
\hline Education Level & & & & \\
\hline No formal Education & $25.8(27.2)$ & $62.8(66.3)$ & $91.5(89.6)$ & $95.7(94.3)$ \\
\hline Primary Education & $55.8(54.5)$ & $36.6(32.6)$ & $8.5(9.3)$ & $4.3(5.7)$ \\
\hline Secondary Education & $17.8(17.3)$ & $0.6(1.1)$ & $(1.1)$ & \\
\hline Tertiary/Vocational Training & 0.6 & & & \\
\hline N & $192(163)$ & $179(164)$ & $182(165)$ & $175(141)$ \\
\hline The values in brackets are data for planting season; $N$ is the sample size \\
\hline
\end{tabular}

In general, intake of energy and nutrients (Table 3) was higher during the planting season than in the harvesting season, except for the intake of calcium in Amudat district. In Abim district, intake of iron and zinc was significantly higher $(\mathrm{p}<0.05)$, in the planting season than in the harvesting season by $5.8 \mathrm{mg} /$ day and $1.4 \mathrm{mg} /$ day. For Kaabong district, intake was significantly higher in planting season compared to harvesting season ( $p<0.05)$ by $1009.6 \mathrm{Kcal} /$ day, $14.7 \mathrm{~g} /$ day, $93.7 \mathrm{~g} /$ day, $392 \mathrm{mg} /$ day, $3.9 \mathrm{mg} /$ day, $1.5 \mathrm{mg} /$ day and $189.3 \mu \mathrm{g} /$ day for energy, proteins, carbohydrates, calcium, iron, zinc and folate, respectively. 
Table 3

Seasonal variability in energy and nutrient intake among women segregated by district

\begin{tabular}{|c|c|c|c|c|c|c|c|c|c|c|c|c|c|c|c|}
\hline \multirow[t]{3}{*}{ District } & \multirow[t]{3}{*}{ Season } & \multicolumn{14}{|c|}{ Energy and Nutrients } \\
\hline & & \multicolumn{2}{|c|}{ Energy (Kcal/d) } & \multicolumn{2}{|c|}{$\begin{array}{l}\text { Proteins } \\
(\mathrm{g} / \mathrm{d})\end{array}$} & \multicolumn{2}{|c|}{$\begin{array}{l}\text { Carbohydrates } \\
\text { (g/d) }\end{array}$} & \multicolumn{2}{|c|}{ Calcium (mg/d) } & \multicolumn{2}{|c|}{ Iron (mg/d) } & \multicolumn{2}{|c|}{ Zinc (mg/d) } & \multicolumn{2}{|c|}{$\begin{array}{l}\text { Folate (dfe) } \\
(\mu \mathrm{g} / \mathrm{d})\end{array}$} \\
\hline & & Mean & SD & Mean & SD & Mean & SD & Mean & SD & Mean & SD & Mean & SD & Mean & SD \\
\hline \multirow[t]{3}{*}{ Abim $(N=164)$} & $A$ & 1691.8 & 1098.3 & 51.5 & 33.7 & 266.9 & 154.7 & 503.5 & 535.6 & 16.6 & 12.1 & 8.1 & 5.5 & 274.6 & 186.0 \\
\hline & B & 1813.8 & 1017.7 & 57.8 & 34.5 & 288.7 & 161.5 & 688.4 & 646.0 & 22.4 & 15.9 & 9.5 & 6.5 & 276.7 & 156.4 \\
\hline & $P<0.05$ & 0.211 & & 0.08 & & 0.138 & & 0.05 & & 0.000 & & 0.026 & & 0.900 & \\
\hline \multirow{3}{*}{$\begin{array}{l}\text { Kaabong } \\
(\mathrm{N}=165)\end{array}$} & $A$ & 1398.8 & 638.0 & 44.6 & 22.3 & 276.8 & 125.7 & 313.9 & 431.4 & 13.8 & 6.6 & 7.3 & 3.8 & 120.9 & 77.9 \\
\hline & B & 2408.4 & 1044.5 & 59.3 & 27.3 & 370.5 & 156.9 & 705.9 & 505.1 & 17.7 & 9.4 & 8.8 & 4.6 & 310.2 & 163.9 \\
\hline & $P<0.05$ & 0.000 & & 0.000 & & 0.000 & & 0.000 & & 0.000 & & 0.001 & & 0.000 & \\
\hline \multirow{3}{*}{$\begin{array}{l}\text { Moroto } \\
(\mathrm{N}=167)\end{array}$} & A & 1681.0 & 885.5 & 47.7 & 25.1 & 279.7 & 128.1 & 441.2 & 397.7 & 15.0 & 8.5 & 6.9 & 3.9 & 181.4 & 125.8 \\
\hline & B & 2052.7 & 1002.8 & 54.7 & 27.2 & 336.9 & 166.9 & 438.8 & 327.6 & 16.7 & 8.9 & 7.8 & 4.2 & 252.0 & 151.7 \\
\hline & $P<0.05$ & 0.0 & & 0.007 & & 0.000 & & 0.95 & & 0.051 & & 0.018 & & 0.000 & \\
\hline \multirow{3}{*}{$\begin{array}{l}\text { Amudat } \\
(\mathrm{N}=142)\end{array}$} & A & 1898.3 & 708.7 & 54.8 & 23.7 & 323.5 & 127.8 & 1074.4 & 659.6 & 9.9 & 4.1 & 10.1 & 4.2 & 137.4 & 51.4 \\
\hline & B & 2150.1 & 764.8 & 55.7 & 23.5 & 394.4 & 138.5 & 932.5 & 560.2 & 13.3 & 5.2 & 11.2 & 4.5 & 184.9 & 68.1 \\
\hline & $P<0.05$ & 0.003 & & 0.714 & & 0.000 & & 0.042 & & 0.000 & & 0.026 & & 0.000 & \\
\hline
\end{tabular}

Similarly, In Moroto district, intake of energy, proteins, carbohydrates, zinc and folate was significantly higher $(p<0.05)$, in planting season than in harvesting season by $371.7 \mathrm{Kcal} /$ day, $7.0 \mathrm{~g} /$ day, $57.2 \mathrm{~g} / \mathrm{day}, 0.9 \mathrm{mg} /$ day, and $70.6 \mu \mathrm{g} /$ day. On the other hand, in Amudat district, energy, carbohydrates, iron, zinc and folate intake were significantly higher $(\mathrm{p}<0.05)$ in planting season than harvesting season by $251.8 \mathrm{Kcal} / \mathrm{day}, 70.9 \mathrm{~g} / \mathrm{day}, 3.4 \mathrm{mg} / \mathrm{day}, 1.1 \mathrm{mg} / \mathrm{day}$, and $47.5 \mu \mathrm{g} / \mathrm{day}$, respectively, while calcium intake was significantly higher $(p<0.05)$ in harvesting season than in planting season by $141.9 \mathrm{mg} / \mathrm{day}$.

In general, irrespective of the district, physiological status and season, household consumption of plant-based foods was far higher than intake of animalbased foods (Table 4). Among the plant-based foods, intake was dominated by starchy stables, dark green leafy vegetables and legumes, nuts and seeds. In the case of animal-based foods, consumption of milk was highest, followed by other meat and fish, eggs, and organ meat. The highest proportion of households that consumed milk was in Amudat, followed by Moroto, Kaabong and Abim. 
Table 4

Proportion of participants who consumed various food groups segregated by physiological status, season and district

\begin{tabular}{|c|c|c|c|c|c|c|c|c|c|c|c|c|}
\hline \multirow[b]{2}{*}{ District } & \multirow[b]{2}{*}{$\begin{array}{l}\text { Physiological } \\
\text { status }\end{array}$} & \multirow[b]{2}{*}{ Seasons } & \multirow[b]{2}{*}{$\mathbf{N}$} & \multicolumn{9}{|c|}{ Proportion (\%) of women of child bearing age that consumed various food groups } \\
\hline & & & & $\begin{array}{l}\text { Starchy } \\
\text { staples }\end{array}$ & $\begin{array}{l}\text { Dark green } \\
\text { Leafy } \\
\text { Vegetables }\end{array}$ & $\begin{array}{l}\text { Other } \\
\text { Vitamin A } \\
\text { rich fruits } \\
\text { \&Vegetables }\end{array}$ & $\begin{array}{l}\text { Other Fruits } \\
\text { \&Vegetables }\end{array}$ & $\begin{array}{l}\text { Organ } \\
\text { meat }\end{array}$ & $\begin{array}{l}\text { Meat } \\
\text { and } \\
\text { fish }\end{array}$ & Eggs & $\begin{array}{l}\text { Legumes, } \\
\text { nuts and } \\
\text { seeds }\end{array}$ & $\begin{array}{l}\text { Milk and } \\
\text { milk } \\
\text { products }\end{array}$ \\
\hline \multirow[t]{6}{*}{ Abim } & Lactating & A & 65 & 76.8 & 73.8 & 18.7 & 67.7 & 1.5 & 14.6 & 12.5 & 87.7 & 9.2 \\
\hline & & B & 95 & 97.9 & 68.4 & 7.5 & 64.5 & 0 & 13.2 & 4.2 & 89.5 & 3.15 \\
\hline & Pregnant & A & 65 & 84.4 & 85.2 & 27.1 & 63.9 & 0 & 23.4 & 14.5 & 96.7 & 17.5 \\
\hline & & B & 20 & 95 & 90 & 25 & 85 & 0 & 7.5 & 0 & 95 & 5 \\
\hline & $\begin{array}{l}\text { Non } \\
\text { Pregnant }\end{array}$ & A & 62 & 86.9 & 77 & 32.4 & 65.6 & 6.6 & 20.9 & 10 & 95.1 & 16.1 \\
\hline & & B & 49 & 93.9 & 75 & 20.4 & 67.3 & 2 & 9.15 & 2 & 85.7 & 2 \\
\hline \multirow[t]{6}{*}{ Kaabong } & Lactating & A & 64 & 100 & 89.1 & 32.8 & 83.3 & 1.6 & 31.3 & 15.6 & 96.9 & 36.2 \\
\hline & & B & 92 & 100 & 91.3 & 16.3 & 46.7 & 0 & 20.7 & 4.3 & 56.5 & 54.3 \\
\hline & Pregnant & A & 63 & 95.2 & 87.3 & 22.3 & 62.3 & 1.6 & 23.3 & 12.7 & 65.1 & 30.95 \\
\hline & & B & 19 & 100 & 100 & 5.3 & 42.1 & 0 & 5.3 & 0 & 42.1 & 36.8 \\
\hline & $\begin{array}{l}\text { Non } \\
\text { Pregnant }\end{array}$ & $A$ & 63 & 98 & 85.7 & 37.3 & 82.5 & 4.8 & 25.4 & 4.8 & 81 & 26.2 \\
\hline & & B & 54 & 100 & 83.3 & 11.1 & 44.4 & 0 & 14.8 & 7.4 & 70.4 & 46.3 \\
\hline \multirow[t]{6}{*}{ Moroto } & Lactating & $A$ & 68 & 100 & 92.6 & 22.1 & 36.8 & 1.5 & 14.7 & 4.4 & 60.3 & 58.8 \\
\hline & & B & 104 & 99 & 91.3 & 17.3 & 55.8 & 1 & 8.7 & 3.8 & 57.7 & 40.2 \\
\hline & Pregnant & $A$ & 63 & 100 & 84.1 & 12.7 & 55.6 & 4.8 & 12.8 & 4.8 & 65.1 & 50.8 \\
\hline & & B & 14 & 100 & 71.4 & 42.9 & 57.1 & 0 & 25 & 7.1 & 71.4 & 50 \\
\hline & $\begin{array}{l}\text { Non } \\
\text { Pregnant }\end{array}$ & A & 53 & 98.2 & 78.2 & 7.3 & 44.4 & 1.8 & 10.9 & 0 & 61.8 & 50.9 \\
\hline & & B & 47 & 100 & 91.5 & 34 & 59.6 & 0 & 14.9 & 0 & 76.6 & 38.3 \\
\hline \multirow[t]{6}{*}{ Amudat } & Lactating & A & 70 & 97.1 & 76.8 & 8.7 & 47.8 & 1.4 & 20.3 & 5.8 & 21.7 & 76.6 \\
\hline & & B & 90 & 100 & 82.2 & 2.2 & 22.2 & 0 & 36.7 & 15.6 & 38.9 & 84.4 \\
\hline & Pregnant & $A$ & 62 & 98.4 & 69.4 & 11.3 & 50 & 3.2 & 27.4 & 14.5 & 27.4 & 83.9 \\
\hline & & B & 20 & 100 & 95 & 0 & 40 & 0 & 30 & 10 & 35 & 80 \\
\hline & $\begin{array}{l}\text { Non } \\
\text { Pregnant }\end{array}$ & $A$ & 53 & 98.1 & 69.8 & 9.4 & 43.4 & 0 & 22.6 & 13.2 & 30.2 & 84.9 \\
\hline & & B & 31 & 100 & 80.6 & 6.5 & 12.9 & 0 & 38.7 & 22.6 & 35.5 & 80.6 \\
\hline
\end{tabular}

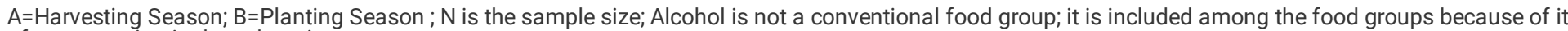
of consumption in the sub-region

The meal times had a similar pattern (Figure 1a and 1c) among all the respondents with the majority taking breakfast and supper while lunch was consumed by a relatively small proportion of women (35-65\%). Alcohol consumption in Amudat was relatively low compared to the situation in Kaabong and Moroto (Figure 1b and 1d). Locally-brewed alcohol was consumed at breakfast, lunch and supper and snack time, either as a full meal or supplementary to full meal.

According to Table 5, the proportion of pregnant women that had inadequate intake of energy, protein, carbohydrate, calcium, iron and zinc was generally higher in the harvesting season than in the planting season. With exception of carbohydrates, most of the pregnant women did not meet the RDA for energy and nutrients. Lactating mothers who did not meet RDAs for energy and nutrients accounted for $86-100 \%$ for folate, $54-97 \%$ for calcium, $66-88 \%$ for zinc, 66 $89 \%$ for protein, $58-84 \%$ for energy, $4-37 \%$ carbohydrates and $15-30 \%$ for iron in decreasing order of magnitude. Similarly, non-pregnant women who did not meet the RDAs was the highest for folate (74-100 \%) followed by calcium (47-96\%), iron (49-96\%) zinc (25-75\%), energy (29-73\%), protein (37-59\%), and carbohydrate (0-18\%) in decreasing order of magnitude. 
Table 5

Levels of inadequacy of energy and nutrient intake among WCBA segregated by physiological status, district and season

\begin{tabular}{|c|c|c|c|c|c|c|c|c|c|c|}
\hline \multirow[t]{2}{*}{ Physiological status } & \multirow[t]{2}{*}{ Districts } & \multirow[t]{2}{*}{ Season } & \multirow[t]{2}{*}{$\mathrm{N}$} & \multicolumn{7}{|c|}{ Proportion (\%) that had adequate intake of energy and nutrient } \\
\hline & & & & Energy & Protein & Carbohydrates & Calcium & Iron & Zinc & Folate \\
\hline \multirow[t]{8}{*}{ Pregnant Women } & \multirow[t]{2}{*}{ Abim } & A & 65 & 84.6 & 87.7 & 38.5 & 92.3 & 93.8 & 92.3 & 95.4 \\
\hline & & B & 20 & 75 & 75 & 15 & 85 & 75 & 75 & 100 \\
\hline & \multirow[t]{2}{*}{ Kaabong } & $A$ & 63 & 90.5 & 84.1 & 19 & 92.1 & 95.2 & 88.9 & 100 \\
\hline & & B & 19 & 36.8 & 68.4 & 0 & 68.4 & 78.9 & 63.2 & 100 \\
\hline & \multirow[t]{2}{*}{ Moroto } & $A$ & 63 & 69.8 & 79.4 & 25.4 & 92.1 & 88.9 & 84.1 & 100 \\
\hline & & B & 14 & 42.9 & 64.3 & 28.6 & 100 & 85.7 & 71.4 & 92.9 \\
\hline & \multirow[t]{2}{*}{ Amudat } & $A$ & 62 & 64.5 & 85.5 & 11.3 & 45.2 & 100 & 67.7 & 100 \\
\hline & & B & 20 & 35 & 70 & 0 & 50 & 95 & 50 & 100 \\
\hline \multirow[t]{8}{*}{ Lactating Mothers } & \multirow[t]{2}{*}{ Abim } & $A$ & 65 & 67.7 & 72.3 & 36.9 & 86.2 & 18.5 & 75.4 & 86.2 \\
\hline & & B & 95 & 73.7 & 72.6 & 36.8 & 82.1 & 16.8 & 73.7 & 89.5 \\
\hline & \multirow[t]{2}{*}{ Kaabong } & A & 64 & 84.4 & 89.1 & 25 & 96.9 & 18.7 & 87.5 & 98.4 \\
\hline & & B & 92 & 41.3 & 66.3 & 14.1 & 78.3 & 15.2 & 71.7 & 88 \\
\hline & \multirow[t]{2}{*}{ Moroto } & A & 68 & 63.2 & 76.5 & 20.6 & 85.3 & 17.6 & 77.9 & 95.6 \\
\hline & & B & 104 & 57.7 & 74 & 15.4 & 92.3 & 18.3 & 81.7 & 96.2 \\
\hline & \multirow[t]{2}{*}{ Amudat } & A & 70 & 58.6 & 72.9 & 21.4 & 54.3 & 30 & 65.7 & 100 \\
\hline & & B & 90 & 57.8 & 80 & 4.4 & 62.2 & 20 & 66.7 & 100 \\
\hline \multirow[t]{8}{*}{ Non-Pregnant Women } & \multirow[t]{2}{*}{ Abim } & $A$ & 62 & 54.8 & 53.2 & 17.7 & 87.1 & 64.5 & 56.5 & 74.2 \\
\hline & & B & 49 & 40.8 & 36.7 & 10.2 & 73.5 & 49 & 42.9 & 73.5 \\
\hline & \multirow[t]{2}{*}{ Kaabong } & A & 63 & 73 & 58.7 & 14.3 & 93.7 & 74.6 & 65.1 & 98.4 \\
\hline & & B & 54 & 27.8 & 37 & 3.7 & 75.9 & 68.5 & 51.9 & 79.6 \\
\hline & \multirow[t]{2}{*}{ Moroto } & $A$ & 55 & 65.5 & 60 & 9.1 & 92.7 & 69.1 & 74.5 & 94.5 \\
\hline & & B & 47 & 40.4 & 48.9 & 8.5 & 95.7 & 70.2 & 68.1 & 87.2 \\
\hline & \multirow[t]{2}{*}{ Amudat } & A & 53 & 50.9 & 43.4 & 7.5 & 47.2 & 96.2 & 41.5 & 100 \\
\hline & & B & 31 & 29 & 41.9 & 0 & 54.8 & 87.1 & 25.8 & 100 \\
\hline \multicolumn{11}{|c|}{ 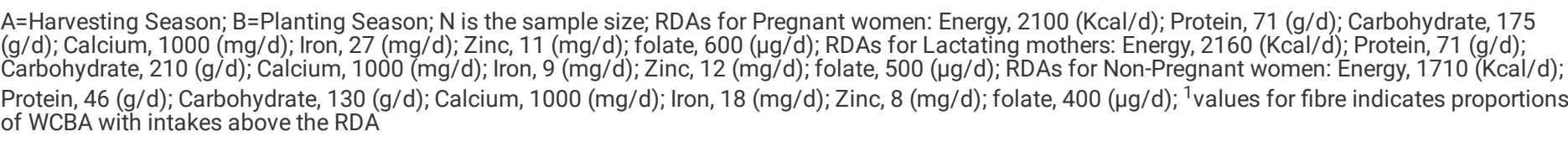 } \\
\hline
\end{tabular}

The socio-economic and demographic predictors of inadequate intake of energy and nutrients vary between seasons and among nutrients (Table 6 ). For energy in the harvesting season, being a lactating or breastfeeding mother increased inadequacy of intake $(\beta$ : $0.152 ; p<0.05)$. Inadequacy in intake of calcium significantly reduced due to an increase age ( $\beta$ : -0.099) and occupation of the household head ( $\beta:-0.111)$ during harvesting season while inadequacy in the intake of the same nutrient increased $(p<0.05)$ during harvesting $(\beta: 0.100)$ and planting season $(\beta: 0.199)$ due to the occupation of the spouse. Inadequacy in the intake of zinc increased $(p<0.05)$ due to occupation of the spouse $(\beta: 0.126)$. Inadequacy in the intake of folate increased $(p<0.05)$ due to an increase in age ( $\beta$ : 0.090) during planting season. As far as vitamin A is concerned, inadequacy of intake increased $(p<0.05)$ due to being married $(\beta$ : 0.127$)$, occupation of the spouse ( $\beta$ : 0.135) and the number of women married in the household ( $\beta$ : 0.132) during harvesting season. For the same nutrient during harvesting season inadequacy of intake reduced $(p<0.05)$ due to an increase in age $(\beta:-0.126)$, occupation of the household head $(\beta$ : -0.151$)$, education of the household head ( $\beta$ : -0.229). Further, education of the spouse reduced inadequacy of intake of vitamin $A$ during both harvesting ( $\beta$ : -0.082$)$ and planting seasons ( $\beta$ : -0.114). 
Table 6

Linear regression analysis of socio-demographic predictors of inadequate intake of energy and nutrients among WCBA segregated by season

\begin{tabular}{|c|c|c|c|c|c|c|c|c|}
\hline \multirow[t]{2}{*}{ Socio-demographic predictors } & \multirow[t]{2}{*}{ Season } & \multicolumn{7}{|c|}{ Inadequacy of Energy and nutrient intake ${ }^{1}$} \\
\hline & & Energy & Proteins & Calcium & Iron & Zinc & Folate (dfe) & Vitamin A (rae) \\
\hline \multirow[t]{2}{*}{ Pregnancy $\left(\mathrm{X}_{1}\right)$} & A & -0.059 & 0.036 & 0.004 & 0.029 & 0.033 & 0.027 & -0.021 \\
\hline & B & -0.008 & -0.008 & -0.008 & -0.007 & 0.018 & 0.012 & -0.055 \\
\hline \multirow[t]{2}{*}{ Lactating//breastfeeding $\left(\mathrm{X}_{2}\right)$} & A & $0.152^{\star}$ & -0.003 & 0.007 & 0.022 & 0.001 & -0.007 & 0.036 \\
\hline & B & 0.016 & 0.015 & 0.019 & -0.007 & 0.005 & 0.015 & -0.054 \\
\hline \multirow[t]{2}{*}{ Age $\left(X_{3}\right)$} & A & -0.011 & -0.040 & $-0.099 *$ & -0.040 & -0.045 & -0.024 & $-0.126^{*}$ \\
\hline & B & 0.043 & -0.022 & 0.024 & 0.001 & -0.049 & $0.090^{*}$ & -0.007 \\
\hline \multirow[t]{2}{*}{ Polygamous $\left(\mathrm{X}_{4}\right)$} & A & 0.024 & 0.036 & 0.026 & 0.036 & 0.036 & 0.037 & 0.013 \\
\hline & B & 0.057 & 0.096 & 0.018 & 0.063 & 0.073 & 0.067 & 0.055 \\
\hline \multirow[t]{2}{*}{ Marital status (married) $\left(X_{5}\right)$} & A & -0.006 & 0.006 & 0.017 & -0.009 & 0.009 & -0.008 & $0.127 *$ \\
\hline & B & -0.033 & -0.009 & 0.018 & -0.070 & 0.039 & -0.063 & 0.041 \\
\hline \multirow[t]{2}{*}{ Occupation of household head $\left(X_{6}\right)$} & A & -0.049 & -0.057 & $-0.111 *$ & -0.028 & -0.059 & -0.055 & $-0.151^{\star}$ \\
\hline & B & -0.019 & -0.037 & -0.062 & -0.034 & -0.086 & 0.034 & -0.070 \\
\hline \multirow[t]{2}{*}{ Occupation of the spouse (woman) $\left(X_{7}\right)$} & A & -0.014 & 0.040 & $0.100^{*}$ & 0.015 & 0.045 & 0.044 & $0.135^{\star}$ \\
\hline & $\mathrm{B}$ & -0.019 & 0.017 & $0.199 *$ & -0.016 & $0.126^{*}$ & -0.089 & -0.087 \\
\hline \multirow[t]{2}{*}{ Education level of household head $\left(X_{8}\right)$} & A & -0.042 & 0.043 & -0.066 & 0.071 & 0.035 & 0.063 & $-0.229 *$ \\
\hline & B & -0.043 & 0.002 & -0.002 & 0.069 & -0.078 & 0.109 & 0.063 \\
\hline \multirow[t]{2}{*}{ Education level of spouse (woman) $\left(X_{9}\right)$} & A & -0.038 & 0.005 & 0.002 & 0.007 & 0.006 & 0.012 & $-0.082^{\star}$ \\
\hline & B & -0.052 & 0.019 & -0.065 & 0.091 & 0.026 & 0.050 & $-0.114^{\star}$ \\
\hline \multirow[t]{2}{*}{ Number of women married $\left(X_{10}\right)$} & A & -0.028 & 0.005 & 0.056 & -0.002 & 0.007 & -0.009 & $0.132^{\star}$ \\
\hline & B & 0.057 & 0.080 & 0.049 & 0.001 & 0.078 & 0.044 & -0.021 \\
\hline
\end{tabular}

A and B denote harvesting and planting seasons, respectively; * The demographic factor is a predictor at $5 \%$ significance level. ${ }^{1}$ Regression coeffiients ( $\beta$ ) of inadequate intake are presented for energt and nutrients (proteins, calcium, iron, zinc, folate and vitamin $\mathrm{A}$ )

\section{Discussion}

Results presented in Table 2 suggests low socio-economic status characterized by subsistence farming, low education levels, low occupation levels, polygamous family settings, conditions that predispose WCBA to poor dietary intake and consequently, nutrition status. Such low socio-economic status coupled with complex demographic factors can present a critical bottle neck to the success of nutrition interventions in Karamoja sub-region. From a policy perspective, efforts that lead to improvement of such socio-demographic and economic conditions are likely to have a positive nutrition outcome among WCBA in Karamoja sub-region.

The result (Table 3) indicates that generally, the intake of energy and nutrients was significantly higher during planting season than harvesting season. This is contrary to what is expected during harvesting season. However, according to FEWWSNET 2019 report [42], food security begins to improve in Karamoja as the harvest begins and sorghum prices decline. One of the probable reasons is based on the observation during data collection that harvesting of most of staple foods such as sorghum span up to February and food was still adequate at the households during the second phase of data collection (planting season). The high proportion of pregnant women failing to meet RDAs for folate, iron and zinc (Table 5) can be attributed to their high micronutrient requirements in this physiological category than women in other physiological status [40] and consumption of foods poor in micronutrients (Table 4). This suggests that women were generally nutritionally deficient before they conceived and experienced even higher deficiencies during pregnancy and lactation owing to their failure to meet the increased energy and nutrient requirements. Nutrient intake in the prenatal period is one of the most important determinants of fetal growth and development, and supports maternal health [43-45]. During pregnancy, dietary energy and nutrient requirement demands are increased because of raised metabolism, blood volume and red cell mass expansion in pregnant women, and the delivery of nutrients to the fetus [46]. Such high demand for nutrients and energy makes pregnant women more vulnerable to malnutrition resulting in both short term effects such as miscarriages, low birth weight, low maternal weight, frequent disease episodes and long term effects such as non-communicable diseases (obesity, type 2 diabetes, hypertension and cardiovascular diseases) in later life [47]. The result therefore implies that pregnant women in Karamoja sub-region are predisposed to inadequate dietary intake which can impact negatively fetal growth and later on the health and nutrition status of the children. 
As shown in Table 5, most of the non pregnant/non lactating mothers did not meet RDAs for micronutrients in both seasons. This implies that from nutritional point of view, most mothers conceive when they are undernourished. The nutritional demand by lactating women is also considerably greater than when pregnant, while diet can affect the synthesis, composition, and secretion of milk [48]. Mothers who are well nourished during pregnancy will have adequate fat and other nutrient reserves to fall back on when lactating [49]. It is apparent that women in Karamoja sub-region do not consume adequate nutrients to support their health and the health of children that nutritionally depend on them. Compromised nutrient intake during the critical period immediately before and following conception can adversely influence pregnancy outcome, increases risk of birth defects, can alter nutrient composition of breast milk, condition infants and children to altered growth trajectories and predisposes them to chronic diseases in later stage of life [50]. While the effects of pre-pregnancy dietary intake are not well characterized, improvements prior to pregnancy may decrease the risk of poor maternal and fetal outcomes [31].

As shown in Table 4, plant-based foods constitute a major part of the household diet in Karamoja sub-region and consumption varies from season to season. This consistent with the literature that most diets in a SSA are plant based [51]. The positive contributions of such plant-based foods to micronutrients and other bioactive substances [52] are of limited by antinutritional factors (e.g; phytates, polyphenols, oxalates, tannins) [53, 54] affecting already heightened nutrient needs of WCBA in Karamoja sub-region.

Regarding seasonality, a similar study [55] that examined dietary diversity and the nutritional status of women in rural Burkina Faso reported that dietary diversity scores (DDSs) were sensitive to seasonal variations. Their findings are in agreement with the current study (Table 3 ) which showed variation in energy and nutrient intake and consumption of food groups between the harvesting and the planting seasons. Whereas it is generally recommended that pregnant women should consume three meals and two or more snacks per day to reduce the risk of preterm delivery [56], this was not the case for WCBA in Karamoja sub-region (Figure 1.1a and 1.1c) and was worsened by consumption of alcohol by WCBA (Figure 1.1b and 1.1d). Prolonged periods of time without food may induce physiological stress during pregnancy [56] while alcohol consumption increases the risk of physical and mental damage to their babies referred to fetal alcohol syndrome [57] adversely affect micronutrient absorption and availability during that physiological state [30]. During period of breastfeeding, alcohol consumption may place newborns at an additional disadvantage as teratogenic effects of alcohol are increased when micronutrients such as iron, zinc and choline are deficient [30]. The habitual intake of alcohol in Karamoja by WCBA observed in the current study suggests that children in Karamoja sub-region are more likely to experience mental and behavioural challenges such as deficits in cognitive functioning (such as general intellectual functioning, learning of new verbal information, and performance on visual-spatial tasks) and fine- and gross-motor performance [58]. It can therefore be asserted that WCBA in Karamoja sub-region are at high risk of malnutrition and poor health during the season of inadequate food intake (harvesting season), and that these risks have important implications for the well-being and development of children in the community.

Linear regression on the 10 independent variables reported in the current study (Table 6) significantly predicted inadequate intake of energy, and selected mircronutrients (calcium, zinc, folate and vitamin A) among WCBA depending on the seasons. It is not surprising to note that being a lactating mother predicted limitations in the intake of energy. This is because lactation/breastfeeding is often associated with increased energy need, requiring the mothers to increase dietary energy intake above that recommended for normal adult women to support breast milk production and prevent maternal malnutrition [59]. Unfortunately, in Karamoja sub-region, the positive coefficients for inadequate energy intake imply that energy among lactating mothers was low. This situation has serious ramifications for nutrition and health wellbeing of these mothers and children in Karamoja sub-region. This is because previous studies have indicated that inadequate energy intake leads to poor health and nutrition outcomes [60] and possibly increased risk of mortality [61, 62].

Other socio economic and demographic factors such as maternal age and education have previously been associated with dietary patterns and nutrition outcomes among mothers [63]. However, the current study (Table 6) indicates that a unit increase in maternal age and occupation of the household head was associated with a decrease in inadequate intake of calcium but increased inadequacy of intake of folate among WCBA. In addition, increase in education level of both the spouse and the household head was associated with a decrease in inadequacy of intake of vitamin A. A reduction in inadequacy of calcium intake with age suggests that pregnant and lactating women are less likely to experience calcium deficiency as they grow old. However, this is a subject matter proposed for further investigation. The findings regarding education level are consistent with a study involving 530 pregnant women at Ile-lfe in Nigeria [61], which indicated that overall, there was a significant relationship between the level of education and knowledge and dietary intake. Education plays a key role in determining maternal under-nutrition [64]. According to Serbesa et al.[65], education status of pregnant women and lactating mothers affected nutrition in the sense that being educated was associated with a higher income, ability to make better decisions for her nutrition and that of the child. The authors further argued that educated pregnant women and lactating mothers were more careful about what they ate than the uneducated counterparts. A similar study [66] also affirmed that antenatal mothers with good education background had higher nutritional knowledge and enhanced understanding of information disseminated through mass media. However, the results of the current study (Table 2) indicate high proportion of women who never attained any formal education, thus, suggesting limited ability of WCBA in Karamoja sub-region to comprehend nutrition information provided. Considering the significance of nutrition information in fostering good nutrition behaviours $[67,68]$, adult education could be implemented to improve education status of WCBA in Karamoja sub-region. Occupation of women limited the intake of calcium, zinc and vitamin A depending on season and nutrient type (Table 6). The observed disparity in the influence of occupation on intake of nutrients in the current study might have been confounded by such dichotomy. This is consistent with the long-held view that results of regression models should be interpreted with care [69], taking in to account the dichotomy that exists in terms of types and quantity of foods available for consumption between planting and harvesting seasons by reporting the adjusted coefficients [70]. The influence of occupation on maternal nutrition was argued in previous studies that women who are employed outside the home for long duration have less leisure time because of work pressure, and hence they cannot take proper care of their health and frequently neglect dietary intake [71]. For the case of Karamoja, due to low education attainment, most of the inhabitants are not formally employed. Inadequacy in the intake levels of nutrient due to occupation could arise from the fact that most of the women engage in subsistence agriculture where they spend long hours in the garden without paying attention to their dietary intake.

Being married is generally believed to be of benefit for maternal nutrition. It has been argued that being married enhances family income and wealth, provide social support and other noneconomic resources that help individuals withstand periods of economic uncertainty or stress, though the benefits of marital support may be smaller for women than men [72]. However, the results of the current study indicate that being married was associated with increased 
inadequacy of vitamin A intake among WCBA. Thus, illustrating from a nutrition point of view and based on the results, there is limited efficacy of marital support in fostering nutritional wellbeing of WCBA in a food insecure location such as the Karamoja sub-region. The significance of marital status in nutrition wellbeing of WCBA seems to be dependent on the nature of marriage type (monogamy and polygamy). This is because polygamy tends to have a negative effect on energy and nutrients, confirmed by the result that an increase in the number of women married in a household increased inadequacy of intake of vitamin A (Table 6). This finding implies that marrying more than one woman in a food insecure environment as is the case in Karamoja sub-region predisposes WCBA and other vulnerable members of the household such as children to more food and nutrition insecurity, and malnutrition. Considering the positive impact of adequate nutrition on health wellbeing of WCBA, children [73] and human-factor related development [74-77, community dialogue could be attempted to discourage polygamy if food and nutrition security situation in the sub-region persists.

Potential limitations to data collection process were that the data could have been affected by recall bias due to the 24-hour recall period and that the estimates for nutrients did not take into consideration their bioavailability. In addition data were collected once in each season which could have influenced the reliability of the results. Hence, there could have been over estimates or under estimates as a result of measuring the portion sizes. However, because the data were obtained from a fairly large sample size, these findings provide important information regarding the intake levels of energy and nutrients among WCBA.

\section{Conclusion}

This study demonstrated that energy and nutrient intake among WCBA differed between the harvesting and planting seasons, with high levels of variability within each district surveyed. WCBA had inadequate energy and nutrient intake based on the recommended daily allowances. WCBA in largely consume plantbased diets, notably starchy staples and green vegetables, as well as legumes, nuts and seeds. WCBA in Karamoja sub-region, regardless of physiological status consume large amounts of locally-produced alcohol, either as a meal or as a supplement to a meal. Lactation/breastfeeding, age of WCBA, number of women married, education level and occupation of the household head and spouse were the key socio-economic and demographic factors that influenced inadequate intake of energy and nutrients among WCBA depending on season.

Thus, interventions to address maternal undernutrition, food and nutrition security need to reflect fine grained seasonal differences within the sub-region if they are to be successful in achieving good nutrition outcomes for WCBA and their children. Moreover, almost ubiquitously, high levels of illiteracy among women are likely to hamper uptake of interventions aimed at improving maternal nutrition outcomes, unless those interventions are thoughtfully and sensitively conceived and implemented using simple methods such as pictures, practical demonstrations, drammars, music and dance, and community dialogue.

\section{List Of Abbreviations}




\begin{tabular}{|ll|}
\hline ACF & Action Against Hunger \\
\hline DHS & Demographic Health Survey \\
\hline FANTA & European Commission \\
\hline FAO & Food and Nutrition Technical Assistance \\
\hline FEWS Net & Famine Early Warning System Network \\
\hline HDDS & Household Dietary Diversity Sore \\
\hline IPC & Uganda IPC Technical Working Group \\
\hline LMICs & Low and Middle Income Countries \\
\hline NEJOGHA & Network of Climate Journalists of the Greater Horn of Africa \\
\hline OPM & Office of the Prime Minister \\
\hline RDA & Recommended Daily Allowance \\
\hline SSA & Sub-Saharan Africa \\
\hline SPSS & Statistical Package for Social Scientists \\
\hline SUN & Scaling Up Nutrition \\
\hline UBOS & Uganda Bureau of Statistics \\
\hline UNAP & Uganda Nutrition Action Plan \\
\hline UNCST & Uganda National Council for Science and Technology \\
\hline UNDP & United Nations Development Programme \\
\hline UNOCHA & United Nations Office for the Coordination of Humanitarian Affairs \\
\hline UNSCN & United Nations System Standing Committee on Nutrition \\
\hline USAID & United States Agency for International Development \\
\hline WCBA & Women of Child Bearing Age \\
\hline
\end{tabular}

\section{Declarations}

Ethics approval and consent to participate; Ethical approval was obtained from the Uganda National Council of Science and Technology (UNCST). Permission to conduct the study was granted by the Resident District Commissioner (RDC) of the respective districts while verbal consent was also obtained from participants before their enrollment into the study.

Consent for publication; All authors consented to publish this article after a thorough review

Availability of data and materials; The datasets used and/or analysed during the current study are available from the corresponding author on reasonable request.

Competing interests; The authors declare that they have no competing interests" in this section

Funding; This research was funded by Higher Education Authority (HEA) and Irish Aid under the Programme of Strategic Cooperation between Irish Aid and Higher Education and Research Institutes 2007-2011 through Work Package 2 of NOURISH Project

\section{Authors' contributions;}

CM: Conception and design, data collection, analysis and interpretation, drafting of the manuscript

IO-U: Critical review of the draft manuscript

ANK: Critical review of the draft manuscript

DT: Critical review of the draft manuscript

DO: Conception and design, critical review and final approval of the draft manuscript for publication

MB: Critical revision, interpretation, guidance on data analysis, final approval of the draft manuscript

Acknowledgements; Professor Martina Hennesy of Trinity College Dublin, and Professor Nazarious Mbona of Makerere University, the Principle Investigator and the country coordinator of the NOURISH project, respectively, and Professor J.H Nyeko Pen-Mogi, the Principle Investigator of Work Package 2 of the 
NOURISH project at Gulu University, Prof. Massimo Lopascu and Ms. Poonam Saksena provided material support at National University of Singapore, Karamoja Didtrict Local Governments and Resident District Commissioners of Abim, Kaabong, Moroto, and Amudat granted permission to carry out the study.

\section{References}

1. Black RE., Allen LH., Bhutta ZA., Caulfield LE., de Onis M, Ezzati M, Mathers C and Rivera J. Maternal and child undernutrition: Global and regional exposures and health consequences. The Lancet. 2008; 371 (9608): 243-260.

2. Desyibelew HD. and Dadi AF. Burden and determinants of malnutrition among pregnant women in Africa: A systematic review and metaanalysis. PLoS ONE. 2019; 14(9): e0221712.

3. Oh H-K, Kang S, Cho S-H, Ju Y-j, and Faye D. Factors influencing nutritional practices among mothers in Dakar, Senegal. PLoS ONE. 2019; 14 (2): e0211787.

4. Ghosh S, Spielman K, Kershaw M, Ayele K, Kidane Y, Zillmer K, et al. Nutrition-specific and nutrition-sensitive factors associated with mid-upper arm circumference as a measure of nutritional status in pregnant Ethiopian women: Implications for programming in the first 1000 days. PLoS ONE. 2019; 14(3): e0214358.

5. Kimani-Murage EW, Wekesah F, Wanjohi M, Kyobutungi C, Ezeh AC, Musoke, RN, et al. Factors affecting actualization of the WHO breastfeeding recommendations in urban poor settings in Kenya. Maternal and Child Nutrition. 2015; 11: 314-332.

6. Locks LM, Pandey PR, Osei AK, Spiro DS, Adhikari DP, Haselow NJ, et al. Using formative research to design a context-specific behaviour change strategy to improve infant and young child feeding practices and nutrition in Nepal. Maternal and Child nutrition. 201511: 882-896.

7. United States Agency for International Development (USAID) (2015) Multi-sectoral nutrition strategy 2014-2025. The 1000-day window of opportunity: Technical guidance brief. 2015; 1-7.

8. Martorell R. Improved nutrition in the first 1000 days and adult human capital and health American Journal of Human Biology. 2017; 29 (2): doi: 10.1002/ajhb.22952

9. Mameli C, Mazzantini S and Zuccotti GV. Nutrition in the first 1000 days: The origin of childhood obesity. International Journal of Environmental Research and Public Health, 2016; 13: 838.

10. Schwarzenberg SJ, Georgieff MK and AAP Committee on Nutrition. Advocacy for improving nutrition in the first 1000 days to support childhood development and adult health. Pediatrics. 2018; 141(2): e20173716.

11. Kabaran S. Maternal and child nutrition: Importance of the first 1000 days. International Journal of Clinical Nutrition and Dietetics. 2018; 4: 133. https://doi.org/10.15344/2456-8171/2018/133

12. Black RE, Victora CG, Walker SP, Bhutta ZA, Christian P, de Onis M, et al. Maternal and child undernutrition and overweight in low-income and middleincome countries. Lancet. 2013; 382: 27-451.

13. Scaling Up Nutrition (SUN): A framework for action. The Word Express. Inc. SUN. 2011.

14. United Nations System Standing Committee on Nutrition (UNSCN) (2017) Global governance for nutrition and the role of UNSCN, UNSCN.

15. Storeng KT and Puyvalle' AB. Civil society participation in global public private partnerships for health. Health Policy and Planning. 2018 ; 33 : 928-936.

16. Uganda Bureau of Statistics (UBOS) and Macro International Inc. Uganda Demographic and Health Survey (UDHS) 2006. Calverton, Maryland, USA: UBOS and Macro International Inc. 2007.

17. Uganda Bureau of Statistics (UBOS) and ICF International Inc.Uganda Demographic and Health Survey (UDHS) 2016: Key indicators report: UBOS Kampala, and Rockville, Maryland, USA: UBOS and ICF Inc. 2017.

18. Uganda Nutrition Action Plan (UNAP) 2011-2016. Scaling Up Multi-Sectoral Efforts to Establish a Strong Nutrition Foundation for Uganda's Development, Government of Uganda. 2011.

19. Uganda IPC Technical Working Group. Report of the Integrated Food Security Phase Classification (IPC) Analysis For Uganda, IPC Technical Working Group, 2017.

20. Burns J, and Bekele G. (Eds). Livelihood Dynamics in Northern Karamoja: A Participatory Baseline Study for the Growth Health and Governance Program. Feinstein International Center; USAID and Mercy Corps. 2013

21. United States Agency for International Development (USAID) Climate change and conflict in Uganda: The cattle corridor and Karamoja. USAID: Washington DC. 2011.

22. Schniepper N. Dryland commodities and livelihoods in Karamoja. Fairventures worldwide FVW, Stuttgart, Germany. 2013.

23. United Nations Office for the Coordination of Humanitarian Affairs (UN OCHA). Karamoja Sub-Region: Livelihood Zones. UN OCHA, Uganda. 2010

24. Shively G.and J. Hao (2012) A review of agriculture, food security and human nutrition issues in Uganda. Working Paper No.12-3. Department of Agricultural Economics, Purdue University. .......(2007). Accessed 25 May 201

25. Uganda Bureau of Statistics (UBOS). Uganda National Household Survey (UNHS) 2012/2013, UBOS, Kampala, Uganda. 2014

26. Office of Prime Minister (OPM). National food security assessment, OPM, Uganda. 2017

27. Eun SL, Talegawkar SA, Merialdi M and Caulfield LE. Dietary intakes of women during pregnancy in low- and middle-income countries. Public Health Nutrition.2019; 16(8): 1340-1353.

28. Rodríguez-Bernal C, Ramo'n R, Quiles J, Murcia M, Navarrete-Muñoz EM, Vioque J, et al. Dietary intake in pregnant women in a Spanish Mediterranean area: as good as it is supposed to be? Public Health Nutrition. 2012; 16 (8): 1379-1389. 
29. Feldkamp ML, Krikov S, Botto LD, Shaw GM, Carmichael SL, and National Birth Defects Prevention Study. Better diet quality before pregnancy is associated with reduced risk of gastroschisis in Hispanic Women. The Journal of Nutrition Journal of Nutrition 2014; 144 : 1781-1786.

30. May PA, Hamrick KJ, Corbin KD, Hasken JM, Marais A-S, Brooke LE, et al. Dietary intake, nutrition, and fetal alcohol spectrum disorders in the Western Cape Province of South Africa. Reproductive Toxicology. 2014; 46: 31-39.

31. Ramage SM, McCargar LJ, Berglund C., Harber V., Rhonda C, Bell RC, et al. Assessment of pre-pregnancy dietary intake with a food frequency questionnaire in Alberta women. Nutrients. 2015; 7 (8): 6155-6166.

32. Famine Early Warning System Network (FEWSNet)(2014) Food security outlook, East Africa, Uganda. http://www.fews.net (2014). Accessed 5 May 2016.

33. Hedeker D, Gibbons, and Waternaux. Sample size estimation for longitudinal designs with attrition. Journal of Educational and Behavioral Statistics. 1999; 24:70-93.

34. Food and Agriculture Organization (FAO), European Commision (EC) (2010). What to do about Karamoja? Why pastoralism is not the problem but the solution. A food security analysis of Karamoja, FAO/ECHO. 2010

35. United States Agency for International Development (USAID) (2010) Karamoja region food security assessment: Uganda, The Famine Early Warning System Network (FEWS Net). 2010.

36. United States Agency for International Development (USAID) and Food and Nutrition Technical Assistance (FANTA) Programme. Household Dietary Diversity Score (HDDS) for measurement of household food access: Indicator guide version 2, Washington D.C: Food and Nutrition Technical Assistance Project, Academy for Educational Development. 2006

37. Gibson R.S. (2005) Principles of Nutritional Assessment. Second Edition. Published by Oxford University Press, Inc., New York. 2005; 446-450.

38. Hotz C, Lubowa A, Sison C, Moursi M, and Loechl C. A food composition table for Central and Eastern Uganda, HarvestPlus Technical Monograph 9; Washington, D.C and Cali: International Food Policy Research Institute (IFPRI) and International Center for Tropical Agriculture (CIAT). 2012

39. Food and Agriculture Organization (FAO). Minimum dietary energy requirement (Kcal/Person/day). FAO Statistics Division, FAO: Rome. 2008

40. Brown J.E., Isaacs J.S., Beate U.K., Lechtenberg E., Murtaugh M.A., Sharbaugh C., Splett P.L., Stang J. and N.H. Wooldridge. Nutrition Through the Life Cycle. $4^{\text {th }}$ Edition, Wadsworth Cengage Learning. 2011;

41. Nassanga P, Okello-Uma I, and Ongeng D. The status of nutritional knowledge, attitude and practices associated with complementary feeding in a postconflict development phase setting: The case of Acholi sub-region of Uganda. Food Science and Nutrition. 2018; 6: 2374-2385.

42. Network of Climate Journalists of the Greater Horn of Africa (NEJOGHA). Food security begins to improve in Karamoja as the harvest begins and sorghum prices decline https://necjogha.com > 2019/10/02 > food-security (2019). Accessed Jul 2020.

43. Gómez MF, Field CJ, Olstad DL, Loehr S, Ramage S, McCargar LJ, and APrON Study Team. Use of micronutrient supplements among pregnant women in Alberta: results from the Alberta Pregnancy Outcomes and Nutrition (APrON) cohort. Maternal and Child Nutrition. 2015; 11: 497-510.

44. Hanson MA, Bardsley A, De-Regil LM, Moore SE, Okene E, Poston L, et al. The International Federation of Gynecology and Obstetrics (FIGO) recommendations on adolescent, preconception, and maternal nutrition: "Think nutrition first". International Journal of Gynecology and Obstetrics. 2015; 131 (S4): S213-S253

45. King JC. Do we need preconception nutrition interventions to improve birth outcomes beyond the prevention of neural tube defects? Current knowledge and future directions, A summary of pathways or mechanisms linking preconception maternal nutrition with birth outcomes. Journal of Nutrition. 2016; 146 (Suppl): $1437 \mathrm{~S}-44 \mathrm{~S}$.

46. Grieger JA, and Clifton VL. A review of the impact of dietary intakes in human pregnancy on infant birth weight Review. Nutrients. $2015 ; 7: 153-178$.

47. Nana A, and Zema T. Dietary practices and associated factors during pregnancy in northwestern Ethiopia BMC Pregnancy and Childbirth. 2018 ; 18 : 183. https://doi.org/10.1186/s12884-018-1822-1

48. dos Santos Q, Sichieri R, Marchioni DML, and Junior EV. Brazilian pregnant and lactating women do not change their food intake to meet nutritional goals. BMC Pregnancy and Childbirth. 2014; 14:186. https://doi.org/10.1186/1471-2393-14-186

49. Haileslassie K, Afework M, and Meron G. Feeding practices, nutritional status and associated factors of lactating women in Samre Woreda, South Eastern Zone of Tigray, Ethiopia. Nutrition Journal. 2013; 12 (28): DOI: 10.1186/1475-2891-12-28

50. Deshanie R, Bird JK, McBurney MI, and Chapman -Novakofski KM. Nutritional status as assessed by nutrient intakes and biomarkers among women of childbearing age - is the burden of nutrient inadequacies growing in America? Public Health Nutrition. 2014; 18(9): 1658-1669.

51. Fraval S, Hammond J, Bogard JR, Ng'endo M, van Etten J, Herrero M, et al. Food Access Deficiencies in Sub-saharan Africa: Prevalence and Implications forAgricultural Interventions. Frontiers in Sustainable Food Systems. 2019; 3:104. doi: 10.3389/fsufs.2019.00104

52. Charoenkiatkul S, Thiyajai P, and Judprasong K. Nutrients and bioactive compounds in popular and indigenous durian (Duriozibethinusmurr.). Food Chemistry. 2015; 193: 181-186.

53. Agbaire PO. Levels of antinutritional factors in some common leafy edible vegetables of southern Nigeria. African Journal of Food Science and Technology. 2012; 3 (4), 99-101.

54. Maninyam A, Reshma J, and Anu M. Evaluation of fruit peels for some selected nutritional and antinutritional factors. Emergent Life Sciences Research. 2015; 1(2): 13-19.

55. Savy M, Martin-Pre'vel Y, Traissac P, Eymard-Duvernay S, and Delpeuch F. Dietary diversity scores and nutritional status of women change during the seasonal food shortage in rural Burkina Faso. Journal of Nutrition. 2006; 136: 2625-2632.

56. Siega-Riz AM, Herrmann TS, and Savitz DA. Frequency of eating during pregnancy and its effect on preterm delivery. American Journal of Epidemiology. $2001 ; 153$ (7): 647-652. 
57. Awuchi CG, Igwe VS, and Amagwula IO. Nutritional diseases and nutrient toxicities: A systematic review of the diets and nutrition for prevention and treatment. International Journal of Advanced Academic Research. 2020; 6 (1): ISSN: 2488-9849.

58. Mattson SN, Schoenfeld AM, and Riley EP. Teratogenic effects of alcoholon brain and behavior. Alcohol Research \& Health. $2001 ; 25$ (3): $185-191$.

59. Fikawati S, Syafiq A, Purbaningrum RP, and Karima K. Energy Consumption of Lactating Mothers: Current Situation and Problems. Makara J. Health Res. 2014; 18(2): 58-64

60. Tran NT, Nguyen LT, Berde Y, Low YL, Tey SL and T.Huynh DT. Maternal nutritional adequacy and gestational weight gain and their associations with birth outcomes among Vietnamese women. BMC Pregnancy and Childbirth. 2019; 19:468. https://doi.org/10.1186/s12884-019-2643-6

61. Oluleke M O., Ogunwale A O., Arulogun O S, and Adelekan AL. Dietary intake knowledge and reasons for food restriction during pregnancy among pregnant women attending primary health care centers in Ile-Ife, Nigeria. Interna-tional Journal of Population Studies. 2016; 2(1): 103-116.

62. Nguyen PH, Sanghvi T, Kim SS, Tran LM, Afsana K, Mahmud Z, et al. Factors influencing maternal nutrition practices in a large scale maternal, newborn and child health program in Bangladesh. PLoS ONE. 2017; 12 (7): e0179873.

63. Smithers LG, Brazionis L, Golley RK, Mittinty MN, Northstone K, Emmett P, et al. Associations between dietary patterns at 6 and 15 months of age and sociodemographic factors. European Journal Clinical Nutrition. 2012; 66: 658 - 666.

64. Onias MT, and Naimi LL. Barriers to improving maternal, newborn, and child health in Binga District, Zimbabwe. Insights to a Changing World Journal. 2014; (4): 73-84.

65. Serbesa ML, Iffa MT, and Geleto M. Factors associated with malnutrition among pregnant women and lactating mothers in Miesso Health Center, Ethiopia. European Jornal of Midwifery. 2019; 3:13. DOI: https://doi.org/10.18332/ejm/110131

66. Lim ZX, Wong JL, Lim PY, and Soon LK. Knowledge of Nutrition during Pregnancy and Associated Factors among Antenatal Mothers International Journal of Public Health and Clinical Sciences. 2018; 5(1): 2289-7577.

67. Hawkes C. 2013. Promoting healthy diets through nutrition education and changes in the food environment: an international review of actions and their effectiveness. Nutrition Education and Consumer Awareness Group, Food and Agriculture Organization of the United Nations, Rome Italy. 2013.

68. Warren AM, Frongillo EA, Nguyen PH, and Purnima M. Nutrition intervention using behavioral change communication without additional material inputs increased expenditures on key food groups in Bangladesh. The Journal of Nutrition. 2020;150 (5): 1284-1290.

69. Tripepi G, Jager KJ, Stel VS, Dekker FW, and Zoccali C. How to deal with continuous and dichotomic outcomes in epidemiological research: Linear and logistic regression analyses. Nephron Clinical Practice. 2011; 118: c399-c406.

70. McNamee R. (2005) Regression modelling and other methods to control confounding. Occupational and Environmental Medicine. 2005; $62: 500-506$.

71. Pallavi R, Deepa R, and Devaki CS. A Study on Assessment of Nutritional Status and Nutritional Knowledge of Working Women Residing in Hostels at Mysuru City. J Food Process Technol. 2020; 11:841. doi: 10.35248/2157-7110.20.11.841.

72. Hanson KL, Sobal J, and Frongillo EA. Gender and marital status clarify Associations between Food Insecurity and Body. Journal of Nutrition. 2007; 137: 1460-1465.

73. Cetin I. and Laoreti A. The importance of maternal nutrition for health. Journal of Pediatric and Neonatal Individualized Medicine. 2015 ; 4(2): e040220.

74. Martins VJB, Florêncio TMMT, Grillo LP, Franco MCP, Martins PA, Clemente APG, et al. Long-lasting effects of undernutrition. International Journal of Environmental Research and Public Health. 2011; 6: 1817-1846.

75. United Nations Development Programme (UNDP). Africa human development, towards a food secure future. United Nations Development Programme Regional Bureau for Africa (RBA) 1 UN Plaza, New York, USA. 2012.

76. Ecker O, and Breisinger C. The food security system; A new conceptual framework, IFPRI Discussion Paper 01166. 2012.

77. Hassan M, Sayem A, and Chowdhury AH. Food Insecurity and Child Undernutrition: Evidence from BDHS 2011. Journal of Food Security. 2013; 1 (2): 5257.

\section{Figures}



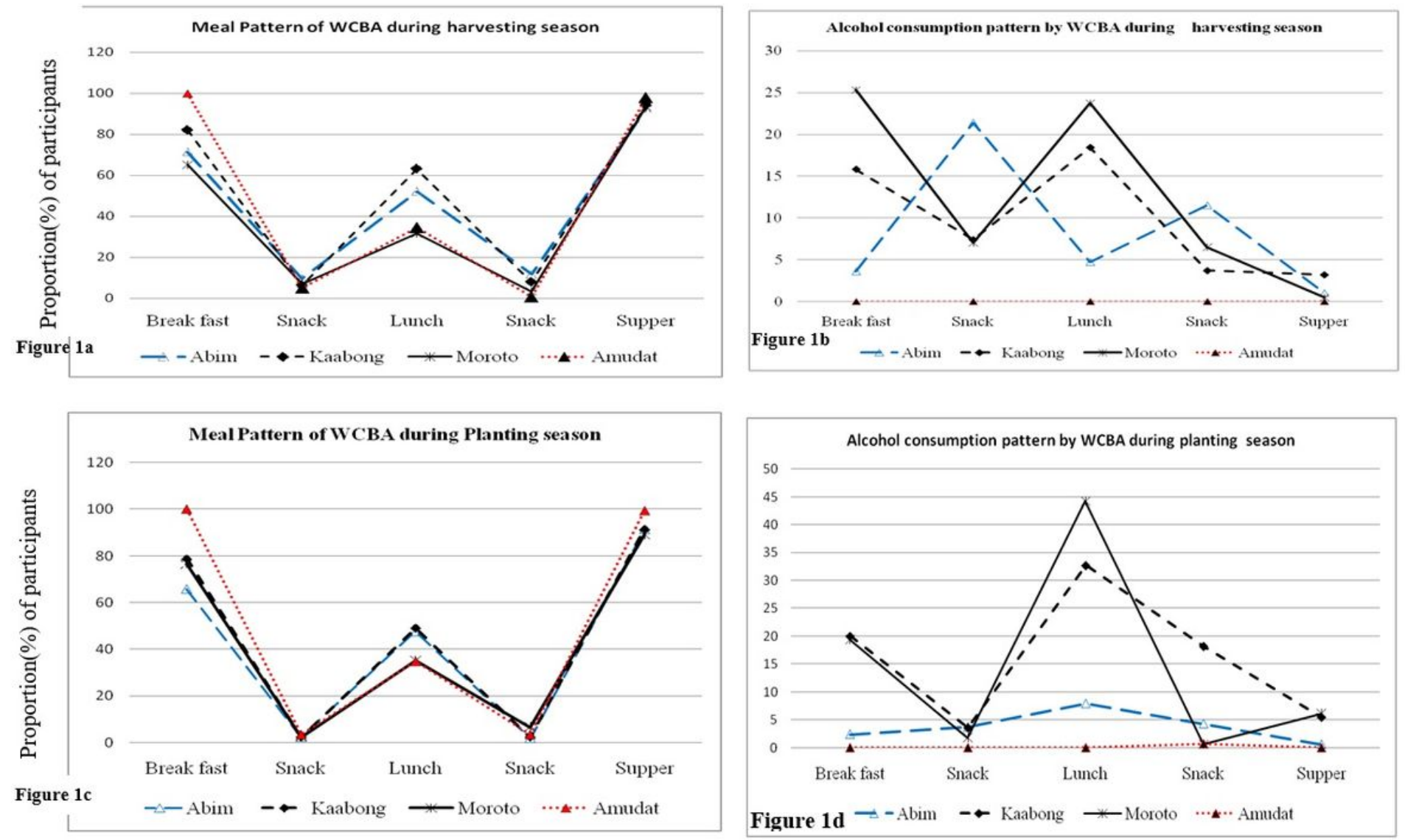

Figure 1

Meal patterns and Alcohol consumption patterns among WCBA according to season (harvesting and planting seasons) and district. 